\title{
PROFESSIONALISM \& ETHICS IN FINANCIAL ADVISING
}

\author{
Balaji Rao D G, Jain University \& Phundo Fintech India Pvt. Ltd., India \\ B Raghavendra Rao, Jain University, India
}

dx.doi.org/10.18374/JIMS-19-1.2

\begin{abstract}
The business of financial advisory has taken center stage and is receiving similar importance to that of a medical profession of which a doctor is the key functionary. While the ultimate objective of doctors is to provide health and ensure physical well-being of their patients, the objective of financial advisors is to efficiently manage "wealth and financial well-being" of the investors. Financial advisory is a profession and also business, because one has to be a professional in the areas of investment management and the person who is advising earns money by way of a fee or commission, just like a doctor earns consultation fee for the services rendered, but the "method" by which the fee or commission is earned would form the fulcrum or core understanding of ethics and professionalism in financial advisory.
\end{abstract}

Keywords: Ethics, Professionalism, Financial Advisor, Qualifications, Regulations 